\title{
Evaluation of SIGLEC1 in the diagnosis of suspected systemic lupus erythematosus
}

Lydia Zorn-Pauly ${ }^{1}$, Anne Sae Lim von Stuckrad², Jens Klotsche ${ }^{3}$, Thomas Rose ${ }^{1}$, Tilmann Kallinich ${ }^{2,3}$, Philipp Enghard ${ }^{4}$, Lennard Ostendorf ${ }^{3,4}$, Marie Burns ${ }^{3}$, Thomas Doerner $^{1}$, Christian Meisel ${ }^{5}$, Udo Schneider ${ }^{1}$, Nadine Unterwalder ${ }^{5}$, Gerd Burmester ${ }^{1}$, Falk Hiepe ${ }^{1}$, Tobias Alexander ${ }^{1,3^{*}}$, Robert Biesen ${ }^{1^{*}}$

${ }^{1}$ Department of Rheumatology and Clinical Immunology, Charité Universitätsmedizin Berlin, corporate member of Freie Universität Berlin and Humboldt-Universität zu Berlin, Berlin, Germany

${ }^{2}$ Pediatric Pneumology, Immunology and Intensive Care Medicine, Charité University Medicine Berlin, Berlin, Germany.

${ }^{3}$ German Rheumatism Research Center Berlin - a Leibniz Institute (DRFZ), Berlin, Germany

${ }^{4}$ Department of Nephrology and Intensive Care Medicine, Universitätsmedizin Berlin, corporate member of Freie Universität Berlin, Humboldt-Universität zu Berlin, and Berlin Institute of Health, Berlin, Germany

${ }^{5}$ Institute for Medical Immunology, Universitätsmedizin Berlin, corporate member of Freie Universität Berlin, Humboldt-Universität zu Berlin, and Berlin Institute of Health, Berlin, Germany

${ }^{*}$ Contributed equally

KEYWORDS: SLE, interferon, biomarker, diagnosis, CD169, SIGLEC1

Address correspondence and reprint request:

Dr. med. Robert Biesen

Department of Rheumatology and Clinical Immunology

Charité University Hospital

Charitéplatz 1

D-10117 Berlin - Germany

E-mail: Robert.Biesen@charite.de 


\section{ABSTRACT}

Objectives: To evaluate and compare the diagnostic accuracy of SIGLEC1, a surrogate marker of type I IFN, with established biomarkers in an inception cohort of systemic lupus erythematosus (SLE).

Methods: SIGLEC1 was analysed by flow cytometry in 232 patients referred to our institution with suspected SLE between October 2015 and September 2020.

Results: SLE was confirmed in 76 of 232 patients (32.8\%) according to the 2019 EULAR/ACR classification criteria and their SIGLEC1 values were significantly higher compared to patients without SLE $(\mathrm{p}<0.0001)$. A sensitivity of $98.7 \%$, a specificity of $82.1 \%$, a negative predictive value (NPV) of $99.2 \%$ and a positive predictive value (PPV) of $72.8 \%$ were calculated for SIGLEC1. Adjusted to the highest reported prevalence of SLE, the NPV and PPV were $>99.9 \%$ and $0.1 \%$, respectively. Using ROC analysis and Delong testing, the area under the curve (AUC) for SIGLEC1 ( $A \cup C=0.95$ ) was significantly higher than for ANA ( $A \cup C=0.88, p=0.031$ ), C3 $(A \cup C=0.83, p=0.001)$ and $C 4 \quad(A \cup C=0.83, p=0.002)$ but not for anti-dsDNA antibodies ( $A \cup C=0.90, p=0.163$ ).

Conclusion: IFN-I pathway activation is detectable in almost all newly diagnosed SLE patients. Thus, a negative test result for SIGLEC1 is powerful to exclude SLE in suspected cases. 


\section{INTRODUCTION}

Systemic lupus erythematosus (SLE) is a heterogeneous autoimmune disease with a complex aetiology, mostly affecting women of childbearing age. The highest prevalence worldwide was reported in a national survey in the USA, with 241 cases per 100000 inhabitants [1].

Type-I interferon (IFN-I) plays a pivotal role in the disease pathogenesis and the type I interferon receptor antagonist anifrolumab had recently been approved by the FDA for the treatment of SLE. Among the multitude of interferon-stimulated genes, we have previously identified SIGLEC1 (sialic acid-binding immunoglobulin-like lectin-1, CD169), an adhesion molecule restricted to cells of the monocyte lineage, as a surrogate marker for activation of the IFN-I pathway [2]. Subsequent studies indicated that SIGLEC1 on monocytes correlates with disease activity and reflects response to targeted treatment approaches in SLE [3-5].

Although commonly determined by several centres utilizing different techniques and surrogate markers, little is known about the IFN-I activity during onset of the disease. Therefore, we aimed to investigate the diagnostic utility of the IFN-I surrogate marker SIGLEC1 in patients with suspected SLE. 


\section{PATIENTS AND METHODS}

In this retrospective study, SIGLEC1 was investigated in patients who have been referred to the Charité - University Medicine Berlin for suspected SLE between October 2015 and September 2020. The study was approved by the local ethics committee (EA2/105/18) and written informed consent was obtained from all participants. Patients were stratified into two groups: A) SLE according to EULAR/ACR 2019 classification criteria [6] or B) SLE-mimicking conditions. The disease activity was determined by the Systemic Lupus Erythematosus Disease Activity Index 2000 (SLEDAI-2K) [7]. Patients pre-treated with a prednisolone dosage exceeding $100 \mathrm{mg} /$ day were excluded from the study as glucocorticoids can suppress the IFN signature in a dose- and time-dependent manner.

\section{Biomarker analysis}

Measurement of SIGLEC1 was described elsewhere and values with a cut-off above 2500 antigens per monocyte were regarded as positive [8].

\section{Statistical analysis}

Statistical analysis was performed by using GraphPad Prism 8.4.3. The Fisher's exact test was used for nominal data. Mann-Whitney- $U$ test (non-parametric) or the unpaired T-test (parametric) were performed for continuously distributed variables. To investigate the SIGLEC1 values during follow-up in SLE patients the Friedmann and Dunn's multiple comparisons test was used. A p-value of $<0.05$ was considered statistically significant. All statistical tests were performed two-sided. ROC analysis was performed for the parameters SIGLEC1, anti-nuclear antibodies (ANA), antidouble-stranded (ds)DNA antibodies, serum complement factors C3 and C4 to evaluate their diagnostic performance. Areas under the curves were compared using the DeLong test [9]. 


\section{RESULTS}

\section{SIGLEC1 is significantly increased in newly diagnosed SLE and has a high negative predictive value}

From 232 patients with suspected SLE referred to our institution, 76 (32.8\%) patients were diagnosed with SLE according to the EULAR/ACR 2019 SLE classification criteria. Details of their demographics, organ manifestations and disease activity are provided in Table S1, and diagnosis of the remaining 156 patients with SLEmimicking conditions are provided in Table S2. SIGLEC1 values were significantly higher in patients with SLE compared to patients without SLE (median MFI 10831 vs. 1341, $\mathrm{p}<0.0001$ ) (Figure 1).

75 of 76 newly diagnosed lupus patients had a threshold value above 2500 molecules per monocyte. Notably, the one lupus patient with a negative SIGLEC1 had received hydroxychloroquine for 3 months prior to diagnosis. For SIGLEC1 values above the threshold, a sensitivity of $98.7 \%$, a specificity of $82.1 \%$, a negative predictive value (NPV) of $99.2 \%$, and a positive predictive value (PPV) of $72.8 \%$ were calculated for the diagnosis of SLE. Notably, PPV and NPV depend on the prevalence of a disease. Considering the highest reported prevalence of SLE worldwide [1], the NPV and PPV was calculated to be $>99.9 \%$ and $0.1 \%$, respectively.

\section{Comparison of the diagnostic performance of SIGLEC1 with established biomarkers}

To compare the diagnostic utility of SIGLEC1 with established biomarkers, we next investigated the Likelihood ratios (LR), which are commonly used to calculate and compare the benefit of performing a diagnostic test. LR's are defined as the change in the probability of the presence or absence of a disease given a positive (LR+) or negative (LR-) test result, and may be further subdivided into four categories according to their diagnostic utility : "none", "weak", "strong" and "superior [10]. By applying these categories, we found that both, negative ANA and SIGLEC1 results were "superior" to exclude SLE, while the other biomarkers were not helpful (Table 1). Conversely, the utility of decreased $C 4$ levels and positive anti-Sm antibodies was "superior" and those of positive anti-dsDNA antibodies and SIGLEC1 values was "strong" in confirming the suspected diagnosis of SLE, while ANA titre or decreased C3 levels were not useful. 
In addition, we compared not only the performance of the tests at a given cut-off, but also across all possible readings by performing ROC curve analyses (Figure 2). AntiSm antibodies could not be considered because they were only measured qualitatively. Area under the curve of SIGLEC1 was highest with 0.95 . Using the DeLong-Test to compare the AUC's, we found that the AUC of SIGLEC1 was significantly higher than that of the ANA ( $A \cup C=0.88, p=0.031), C 3(A \cup C=0.83$, $p=0.001)$ and $C 4(A \cup C=0.83, p=0.002)$. Only the AUC of anti-dsDNA antibodies $(A \cup C=0.90, p=0.163)$ did not differ significantly from that of SIGLEC1.

\section{Most patients retain increased IFN-I activity despite treatment}

Finally, we followed the SIGLEC1 values longitudinally in a subgroup of 26 newly diagnosed SLE patients, from which 6 months follow-up data were available. In these patients, SIGLEC1 values decreased from a median of 10397 at baseline to 8500 at 3 months and 5799 at 6 months of follow-up, respectively (Fig. S1). Nevertheless, IFN-I pathway activation remained detectable in 18 of 26 (69\%) of patients and only 8 of $26(31 \%)$ of patients experienced complete regression of elevated SIGLEC1 levels after 6 months of follow up. Both groups did not significantly differ in clinical disease activity by means of SLEDAI (unpaired t test, $\mathrm{p}=0.563$ ). Fig. S2 shows the SLEDAI of these patients over time. 


\section{DISCUSSION}

In this study, the potential diagnostic utility of the IFN-I biomarker SIGLEC1 for the diagnosis of SLE was investigated in an inception cohort of 76 patients with newly diagnosed SLE and 156 patients with SLE-mimicking conditions. Our data show that negative values of SIGLEC1 at the disease onset are a powerful diagnostic tool to exclude SLE in suspected cases.

Although activation of the IFN pathway in SLE is well recognized, little is known about the diagnostic value of IFN biomarkers. Feng et al. investigated the diagnostic utility of five IFN-stimulated genes for the diagnosis of SLE in 69 pretreated patients with a disease duration of up to 22 years, and described a sensitivity and specificity between 70 and $80 \%$ depending on the cut-off values used [11]. Yuan et al. described a sensitivity of $89 \%$ and a specificity of $69 \%$ for interferon-stimulated gene 15 in an inception cohort of 28 newly diagnosed SLE patients [12]. However, both studies did not compare the diagnostic utility of such IFN biomarkers with established SLE biomarkers.

Increased SIGLEC1 values were detected in virtually all newly diagnosed SLE patients. As a result, a very high negative predictive value of $>99 \%$ and negative likelihood ratio of 0.02 for SIGLEC1 testing was calculated, suggesting that a negative test result allows to exclude SLE with a high probability. The diagnostic benefit of a normal SIGLEC1 value in excluding SLE is comparable to that for a negative ANA test in suspected SLE, to a negative D-dimer for suspected deep venous thrombosis or a negative CRP for suspected giant cell arteritis [13]. Our data suggest that validated, worldwide available interferon biomarkers may further improve diagnostic procedures and, potentially, classification of SLE [14]. With a sensitivity of nearly $100 \%$ in juvenile dermatomyositis [15], a sensitivity of $100 \%$ in monogenic interferonopathies [16], and a sensitivity of $>95 \%$ in early SARS-CoV2 infection [17], SIGLEC1 may also provide a valuable screening tool for other disorders associated with increased IFN-I activity.

The specificity of SIGLEC1 for diagnosing SLE was unexpectedly high, which may be explained by a stringent pre-selection of patients by referral to a tertiary hospital. However, elevated SIGLEC1 values are also detectable in other rheumatic musculoskeletal diseases such as Sjogren's syndrome [18], myositis [15] and viral infections such as HIV [19] or SARS-CoV2 [17]. 
This study has certain limitations. First, the number of included patients in our inception cohort was limited and included a subset of patients who were pre-treated. Second, our data were collected retrospectively in a single centre and validation of our results in a multicentre study is needed. Finally, this study lacks inclusion of other biomarkers established for IFN-I pathway activation.

In conclusion, our data indicate that IFN-I pathway activation is detectable in nearly all patients at onset of SLE, and identifies the interferon biomarker SIGLEC1 as a powerful diagnostic tool to exclude SLE in suspected cases. 


\section{Key Messages}

\section{What is already known about this subject?}

$\Rightarrow$ The activity of type I interferon has been extensively studied in SLE over the past decades, but the diagnostic utility of IFN biomarkers in suspected SLE has been poorly evaluated.

\section{What does this study add?}

$\Rightarrow$ At the time of diagnosis, virtually all SLE patients have increased IFN-I activity as measured by SIGLEC1.

$\Rightarrow$ The negative predictive value of a normal SIGLEC1 expression for exclusion of SLE is comparable to that of a negative ANA test.

$\Rightarrow$ Although SIGLEC1 levels decrease significantly with treatment, the majority of SLE patients retain elevated SIGLEC1 expression after six months.

\section{How might this impact on clinical practice or future developments?}

$\Rightarrow$ The widespread use of easily measurable, validated IFN biomarkers would improve the diagnosis of diseases with increased IFN-I activity in general and SLE in particular. 
Acknowledgements We thank all the patients who participated.

Contributors Study design: RB, TA. Sample collection: LZP, TA, RB, AVS, TK, PE, LO, MB, TD, US, TR, FH, GB. Data analysis: LZP, NU, CM, JK, RB, TA. Tables and figure: LZP, RB, TA. Data interpretation: LZP, RB, TD, TA. Writing of the manuscript: RB, LZP. Critical proofreading of the manuscript: all authors.

Funding The authors have not declared a specific grant for this research from any funding agency in the public, commercial or not-for-profit sectors.

Competing interests None declared.

Patient consent for publication Not required.

Ethics approval: The present study was approved by the ethics committee of the Charité -Universitätsmedizin Berlin under EA2/105/18. All patients gave written informed consent. Patients were not involved in the study planning.

Data availability statement: The data is available upon reasonable request from the corresponding author. 


\section{References}

1. Ward MM: Prevalence of physician-diagnosed systemic lupus erythematosus in the United States: results from the third national health and nutrition examination survey. J Womens Health (Larchmt) 2004, 13(6):713-718.

2. Biesen R, Demir C, Barkhudarova F, Grun JR, Steinbrich-Zollner M, Backhaus M, Haupl T, Rudwaleit M, Riemekasten G, Radbruch A et al: Sialic acidbinding Ig-like lectin 1 expression in inflammatory and resident monocytes is a potential biomarker for monitoring disease activity and success of therapy in systemic lupus erythematosus. Arthritis Rheum 2008, 58(4):1136-1145.

3. Rose T, Grutzkau A, Hirseland H, Huscher D, Dahnrich C, Dzionek A, Ozimkowski T, Schlumberger W, Enghard P, Radbruch A et al: IFNalpha and its response proteins, IP-10 and SIGLEC-1, are biomarkers of disease activity in systemic lupus erythematosus. Ann Rheum Dis 2013, 72(10):1639-1645.

4. Rose T, Grutzkau A, Klotsche J, Enghard P, Flechsig A, Keller J, Riemekasten G, Radbruch A, Burmester GR, Dorner T et al: Are interferon-related biomarkers advantageous for monitoring disease activity in systemic lupus erythematosus? A longitudinal benchmark study. Rheumatology (Oxford) 2017, 56(9):1618-1626.

5. Ostendorf L, Burns M, Durek P, Heinz GA, Heinrich F, Garantziotis P, Enghard P, Richter U, Biesen R, Schneider U et al: Targeting CD38 with Daratumumab in Refractory Systemic Lupus Erythematosus. $N$ Engl J Med 2020, 383(12):1149-1155.

6. Aringer M, Costenbader K, Daikh D, Brinks R, Mosca M, Ramsey-Goldman R, Smolen JS, Wofsy D, Boumpas DT, Kamen DL et al: 2019 European League Against Rheumatism/American College of Rheumatology classification criteria for systemic lupus erythematosus. Annals of the Rheumatic Diseases 2019, 78(9):1151-1159.

7. Gladman DD, Ibanez D, Urowitz MB: Systemic lupus erythematosus disease activity index 2000. J Rheumatol 2002, 29(2):288-291.

8. Stuckrad SLV, Klotsche J, Biesen R, Lieber M, Thumfart J, Meisel C, Unterwalder N, Kallinich T: SIGLEC1 (CD169) is a sensitive biomarker for the deterioration of the clinical course in childhood systemic lupus erythematosus. Lupus 2020, 29(14):1914-1925.

9. DeLong ER, DeLong DM, Clarke-Pearson DL: Comparing the areas under two or more correlated receiver operating characteristic curves: a nonparametric approach. Biometrics 1988, 44(3):837-845.

10. Jaeschke R, Guyatt GH, Sackett DL: Users' guides to the medical literature. III. How to use an article about a diagnostic test. B. What are the results and will they help me in caring for my patients? The Evidence-Based Medicine Working Group. JAMA 1994, 271(9):703-707.

11. Feng X, Huang J, Liu Y, Xiao L, Wang D, Hua B, Tsao BP, Sun L: Identification of interferon-inducible genes as diagnostic biomarker for systemic lupus erythematosus. Clin Rheumatol 2015, 34(1):71-79.

12. Yuan $Y$, Ma H, Ye Z, Jing W, Jiang Z: Interferon-stimulated gene 15 expression in systemic lupus erythematosus : Diagnostic value and association with lymphocytopenia. Z Rheumatol 2018, 77(3):256-262.

13. Costello F, Zimmerman MB, Podhajsky PA, Hayreh SS: Role of thrombocytosis in diagnosis of giant cell arteritis and differentiation of 
arteritic from non-arteritic anterior ischemic optic neuropathy. Eur $J$ Ophthalmol 2004, 14(3):245-257.

14. Wang B, Chen S, Zheng Q, Gao Z, Chen R, Xuan J, Liu Y, Shi G:

Development and initial validation of diagnostic gene signatures for systemic lupus erythematosus. Ann Rheum Dis 2019.

15. Lerkvaleekul B, Veldkamp SR, van der Wal MM, Schatorje EJH, Kamphuis SSM, van den Berg JM, Muller P, Armbrust W, Vastert SJ, Wienke J et al: Siglec-1 expression on monocytes is associated with the interferon signature in juvenile dermatomyositis and can predict treatment response. Rheumatology (Oxford) 2021.

16. Orak B, Ngoumou G, Ebstein F, Zieba B, Goetzke CC, Knierim E, Kaindl AM, Panzer A, Theophil M, Berns $M$ et al: SIGLEC1 (CD169) as a potential diagnostical screening marker for monogenic interferonopathies. Pediatr Allergy Immunol 2021, 32(3):621-625.

17. Doehn JM, Tabeling C, Biesen R, Saccomanno J, Madlung E, Pappe E, Gabriel F, Kurth F, Meisel C, Corman VM et al: CD169/SIGLEC1 is expressed on circulating monocytes in COVID-19 and expression levels are associated with disease severity. Infection 2021, 49(4):757-762.

18. Rose T, Szelinski F, Lisney A, Reiter K, Fleischer SJ, Burmester GR, Radbruch A, Hiepe F, Grutzkau A, Biesen R et al: SIGLEC1 is a biomarker of disease activity and indicates extraglandular manifestation in primary Sjogren's syndrome. RMD Open 2016, 2(2):e000292.

19. Izquierdo-Useros N, Lorizate M, McLaren PJ, Telenti A, Krausslich HG, Martinez-Picado J: HIV-1 capture and transmission by dendritic cells: the role of viral glycolipids and the cellular receptor Siglec-1. PLOS Pathog 2014, 10(7):e1004146. 
medRxiv preprint doi: https://doi.org/10.1101/2021.09.25.21263771; this version posted September 27, 2021. The copyright holder for this preprint (which was not certified by peer review) is the author/funder, who has granted medRxiv a license to display the preprint in perpetuity.

It is made available under a CC-BY-NC-ND 4.0 International license .

\section{Tables:}

\begin{tabular}{|c|c|c|c|c|c|c|c|c|c|c|}
\hline \multicolumn{11}{|l|}{ Table 1} \\
\hline Biomarker & $\begin{array}{l}\text { Cut- } \\
\text { off }\end{array}$ & $\begin{array}{c}\text { Sensitivity } \\
(\%)\end{array}$ & $\begin{array}{c}\text { Specificity } \\
(\%)\end{array}$ & $\begin{array}{l}\text { Negative } \\
\text { predictive } \\
\text { value (\%) }\end{array}$ & $\begin{array}{l}\text { Positive } \\
\text { predictive } \\
\text { value (\%) }\end{array}$ & $\begin{array}{l}\text { Negative } \\
\text { Likelihood } \\
\text { ratio }\end{array}$ & $\begin{array}{l}\text { Positive } \\
\text { Likelihood } \\
\text { ratio }\end{array}$ & $\begin{array}{l}\text { Relevance } \\
\text { for } \\
\text { rule out }\end{array}$ & $\begin{array}{l}\text { Relevance } \\
\text { for } \\
\text { rule in }\end{array}$ & $\begin{array}{l}\text { Diagnostic } \\
\text { odds ratio }\end{array}$ \\
\hline $\begin{array}{l}\text { ANA } \\
\text { (titre) }\end{array}$ & $1: 80$ & 100.0 & 45.8 & 100.0 & 47.5 & 0.00 & 1.85 & superior & none & * \\
\hline $\begin{array}{l}\text { Anti- } \\
\text { dsDNA-Ab } \\
(I U / I)\end{array}$ & 20 & 81.4 & 84.2 & 90.4 & 71.3 & 0.22 & 5.15 & weak & strong & 23.22 \\
\hline $\begin{array}{l}\text { Anti-Sm- } \\
\text { Ab (+/-) }\end{array}$ & neg. & 20.0 & 98.7 & 73.2 & 87.5 & 0.81 & 15.29 & none & superior & 18.98 \\
\hline $\begin{array}{l}\text { C3 } \\
\text { (mg/l) }\end{array}$ & 900 & 65.8 & 82.6 & 82.6 & 65.8 & 0.41 & 3.78 & weak & weak & 9.13 \\
\hline $\begin{array}{l}\text { C4 } \\
(\mathrm{mg} / \mathrm{l})\end{array}$ & 100 & 39.5 & 97.3 & 75.8 & 88.2 & 0.62 & 14.63 & none & superior & 23.53 \\
\hline $\begin{array}{l}\text { SIGLEC1 } \\
\text { (antigens/ } \\
\text { monocyte) }\end{array}$ & 2500 & 98.7 & 82.1 & 99.2 & 72.8 & 0.02 & 5.51 & superior & strong & 348.23 \\
\hline $\begin{array}{l}\text { Table 1: } \\
\text { biomarke } \\
\text { The diagn } \\
\text { ratio (LR) } \\
(2<L R+<5 \\
\text { calculated }\end{array}$ & $\begin{array}{l}\text { Dia } \\
\text { s of } \\
\text { stic } \\
\text { n s } \\
0.2 \\
\text { oy } q\end{array}$ & $\begin{array}{l}\text { nostic } \\
\text { LE } \\
\text { enefit o } \\
\text { erior ( } L \\
R-<0.5 \\
\text { tient of }\end{array}$ & $\begin{array}{l}\text { erfor } \\
\text { a test } \\
+>10 \\
\text { and } n \\
R+\text { al }\end{array}$ & $\begin{array}{l}\text { Ince } \\
\text { n be } \\
\text { R-<0 } \\
\text { e }(1< \\
\text { R-. }\end{array}$ & $\begin{array}{l}\text { ghly } \\
\text { stron } \\
+<2 ; \\
\text { t app }\end{array}$ & $\begin{array}{l}\text { duate } \\
5<\text { LR } \\
<\text { LR- } \\
\text { able d }\end{array}$ & $\begin{array}{c}\text { ccord } \\
10 ; 0 . \\
\text { Diag } \\
\text { to divi }\end{array}$ & $\begin{array}{l}\text { to the } \\
\text { LR }-<0 \\
\text { stic odc } \\
\text { on by ze }\end{array}$ & $\begin{array}{l}\text { blished } \\
\text { kelihood } \\
\text { ); weak } \\
\text { ratio is } \\
\text { o. }\end{array}$ & \\
\hline
\end{tabular}


medRxiv preprint doi: https://doi.org/10.1101/2021.09.25.21263771; this version posted September 27, 2021. The copyright holder for this preprint (which was not certified by peer review) is the author/funder, who has granted medRxiv a license to display the preprint in perpetuity.

It is made available under a CC-BY-NC-ND 4.0 International license .

\begin{tabular}{|c|c|c|c|}
\hline Disease & $\begin{array}{c}\text { SLE } \\
(n=76)\end{array}$ & $\begin{array}{l}\text { SLE-mimicking } \\
\text { conditions }(n=156)\end{array}$ & p-value \\
\hline Female (\%) & 86.8 & 88.5 & ns \\
\hline Age, median years (range) & $\begin{array}{c}33.0 \\
(3-76)\end{array}$ & $\begin{array}{c}38.0 \\
(17-83)\end{array}$ & 0.004 \\
\hline \multicolumn{4}{|l|}{ Therapy (\%) } \\
\hline Therapy naive & 56.6 & 85.3 & 0.001 \\
\hline $\begin{array}{l}\text { Prednisolone dose } \mathrm{mg} / \mathrm{d} \text { median } \\
\text { (range) }\end{array}$ & $\begin{array}{c}0 \\
(0-100)\end{array}$ & $\begin{array}{c}0 \\
(0-30)\end{array}$ & $<0.001$ \\
\hline Prednisolone $\leq 7,5 \mathrm{mg} / \mathrm{d}$ & 15.8 & 5.8 & 0.043 \\
\hline Prednisolone $>7,5 \mathrm{mg} / \mathrm{d}$ & 17.1 & 3.2 & $<0.001$ \\
\hline Hydroxychloroquine & 15.8 & 6.4 & 0.017 \\
\hline Azathioprine & 2.6 & 1.9 & ns \\
\hline Methotrexate & 3.9 & 1.9 & ns \\
\hline Mycophenolate Mofetil & 2.6 & 0.0 & ns \\
\hline Cyclophosphamide & 2.6 & 0.0 & ns \\
\hline \multicolumn{4}{|l|}{ Laboratory values } \\
\hline $\begin{array}{l}\text { SIGLEC1 positive (>2500) (\%) } \\
\text { Median } \\
\text { (range) }\end{array}$ & $\begin{array}{c}98.7 \\
10813 \\
(2099-29314)\end{array}$ & $\begin{array}{c}18.0 \\
1341 \\
(1200-14129)\end{array}$ & $\begin{array}{l}<0.001 \\
<0.001\end{array}$ \\
\hline $\begin{array}{l}\text { ANA positive }(\geq 1: 160)(\%) \\
\text { Median } \\
\text { (range) }\end{array}$ & $\begin{array}{c}100 \\
1: 2560 \\
(160-10240)\end{array}$ & $\begin{array}{c}54.2 \\
1: 160 \\
(0-10240)\end{array}$ & $\begin{array}{l}<0.001 \\
<0.001\end{array}$ \\
\hline Anti-Sm Ab positive (\%) & 20.0 & 1.3 & $<0.001$ \\
\hline $\begin{array}{l}\text { Anti-dsDNA Ab positive (\%) } \\
\text { Median } \\
\text { (range) }\end{array}$ & $\begin{array}{c}81.4 \\
87.5 \\
(3.8-200)\end{array}$ & $\begin{array}{c}15.6 \\
10.1 \\
(0-200)\end{array}$ & $\begin{array}{l}<0.001 \\
<0.001\end{array}$ \\
\hline $\begin{array}{l}\text { Low C3 mg/l (<900) positive (\%) } \\
\text { Median } \\
\text { (range) }\end{array}$ & $\begin{array}{c}65.8 \\
815.0 \\
(80.0-1570.0)\end{array}$ & $\begin{array}{c}17.4 \\
1090.0 \\
(650.0-8460)\end{array}$ & $\begin{array}{l}<0.001 \\
<0.001\end{array}$ \\
\hline $\begin{array}{l}\text { Low C4 mg/l }(<100) \text { positive (\%) } \\
\text { Median } \\
\text { (range) }\end{array}$ & $\begin{array}{c}39.5 \\
110.0 \\
(20.0-380.0)\end{array}$ & $\begin{array}{c}2.7 \\
230.0 \\
(20.0-550.0)\end{array}$ & $\begin{array}{l}<0.001 \\
<0.001\end{array}$ \\
\hline \multicolumn{4}{|l|}{ Clinical characteristics (\%) } \\
\hline Fatigue & 72.7 & 37.1 & $<0.001$ \\
\hline Arthralgias & 68.0 & 57.8 & ns \\
\hline Arthritis & 48.0 & 5.2 & $<0.001$ \\
\hline Raynaud & 42.2 & 17.6 & $<0.001$ \\
\hline Alopecia & 41.7 & 18.4 & $<0.001$ \\
\hline Fever & 40.5 & 7.2 & $<0.001$ \\
\hline Rash & 40.0 & 5.3 & $<0.001$ \\
\hline Photosensitivity & 39.7 & 11.3 & $<0.001$ \\
\hline Myalgias & 32.4 & 13.9 & 0.002 \\
\hline Renal Involvement & 26.3 & 1.9 & $<0.001$ \\
\hline Pleuritis & 24.0 & 5.8 & $<0.001$ \\
\hline Sicca & 23.6 & 20.0 & ns \\
\hline Oral ulcer & 22.7 & 8.7 & 0.006 \\
\hline Pericarditis & 12.0 & 5.8 & ns \\
\hline Vasculitis & 9.3 & 1.3 & 0.006 \\
\hline Myositis & 6.8 & 2.0 & ns \\
\hline CNS Symptoms & 5.3 & 3.9 & ns \\
\hline $\begin{array}{l}\text { SLEDAI } 2 K \text { median } \\
\text { (range) }\end{array}$ & $\begin{array}{c}8 \\
(0-27)\end{array}$ & - & - \\
\hline
\end{tabular}


medRxiv preprint doi: https://doi.org/10.1101/2021.09.25.21263771; this version posted September 27, 2021. The copyright holder for this preprint (which was not certified by peer review) is the author/funder, who has granted medRxiv a license to display the preprint in perpetuity.

It is made available under a CC-BY-NC-ND 4.0 International license .

\begin{tabular}{|c|c|c|c|}
\hline $\begin{array}{l}\text { Diagnosis of SLE-mimicking conditions } \\
\text { patients }(n=156)\end{array}$ & $\begin{array}{l}\text { SIGLEC1 } \\
\text { positive } \\
\text { values } \\
\text { median } \\
\text { (range) }\end{array}$ & $\begin{array}{c}\text { SIGLEC1 } \\
\text { negative } \\
\text { values } \\
\text { median } \\
\text { (range) }\end{array}$ & p-value \\
\hline $\begin{array}{l}\text { No Final Diagnosis (Exclusion of rheumatic } \\
\text { and musculoskeletal diseases) }(n=79)\end{array}$ & $\begin{array}{c}8 \% \\
5800 \\
(2944-14129)\end{array}$ & $\begin{array}{c}92 \% \\
1200 \\
(1200-2373)\end{array}$ & $<0.001$ \\
\hline \multicolumn{4}{|l|}{$\begin{array}{l}\text { Rheumatic and musculoskeletal diseases } \\
(n=63)\end{array}$} \\
\hline $\begin{array}{l}\text { Undifferentiated } \\
\text { Connective Tissue } \\
\text { Disease (UCTD) }(n=30)\end{array}$ & $\begin{array}{l}27 \% \\
6596(2529 \\
10536)\end{array}$ & $\begin{array}{c}73 \% \\
1261(1200 \\
2215)\end{array}$ & $<0.001$ \\
\hline $\begin{array}{l}\text { Mixed Connective } \\
\text { Tissue Disease (MCTD) } \\
(n=7)\end{array}$ & $\begin{array}{c}57 \% \\
8814(3700- \\
10013)\end{array}$ & $\begin{array}{c}43 \% \\
1434(1293- \\
2239)\end{array}$ & 0.018 \\
\hline $\begin{array}{l}\text { Sjögren Syndrome } \\
(n=5)\end{array}$ & $\begin{array}{c}80 \% \\
6257(2668- \\
12320)\end{array}$ & $\begin{array}{l}20 \% \\
1200\end{array}$ & 0.320 \\
\hline $\begin{array}{l}\text { Primary Anti- } \\
\text { Phospholipid Syndrome } \\
(n=1)\end{array}$ & $0 \%$ & $\begin{array}{c}100 \% \\
1200\end{array}$ & / \\
\hline Felty Syndrome $(n=1)$ & $\begin{array}{l}100 \% \\
3960\end{array}$ & $0 \%$ & / \\
\hline Sarcoidosis $(n=1)$ & $0 \%$ & $\begin{array}{c}100 \% \\
1450\end{array}$ & / \\
\hline Fibromyalgia $(n=1)$ & $0 \%$ & $\begin{array}{c}100 \% \\
1740\end{array}$ & / \\
\hline Reactive Arthritis ( $n=2)$ & $0 \%$ & $\begin{array}{c}100 \% \\
1722(1200- \\
2244)\end{array}$ & / \\
\hline $\begin{array}{l}\text { Rheumatoid Arthritis } \\
(n=4)\end{array}$ & $\begin{array}{l}25 \% \\
10203\end{array}$ & $\begin{array}{c}75 \% \\
1200(1200- \\
1959)\end{array}$ & 0.003 \\
\hline Psoriatic Arthritis $(n=2)$ & $0 \%$ & $\begin{array}{c}100 \% \\
1295(1272- \\
1317)\end{array}$ & / \\
\hline Gonarthritis ( $n=2)$ & $0 \%$ & $\begin{array}{c}100 \% \\
1367(1200- \\
1533)\end{array}$ & / \\
\hline Vasculitis ( $n=3)$ & $0 \%$ & $\begin{array}{c}100 \% \\
1389(1200 \\
1391)\end{array}$ & / \\
\hline IgA Nephropathy $(n=1)$ & $\begin{array}{l}100 \% \\
10380\end{array}$ & $0 \%$ & / \\
\hline $\begin{array}{l}\text { Familial Mediterranean } \\
\text { Fever }(n=1)\end{array}$ & $0 \%$ & $\begin{array}{c}100 \% \\
1277\end{array}$ & / \\
\hline $\begin{array}{l}\text { IgG4-related Disease } \\
(n=1)\end{array}$ & $0 \%$ & $\begin{array}{c}100 \% \\
1752\end{array}$ & / \\
\hline Discoid Lupus $(n=1)$ & $0 \%$ & $\begin{array}{c}100 \% \\
1200\end{array}$ & / \\
\hline \multicolumn{4}{|l|}{ Other organ specific diseases $(n=12)$} \\
\hline $\begin{array}{l}\text { Inflammatory Bowel } \\
\text { Disease }(n=1)\end{array}$ & $0 \%$ & $\begin{array}{c}100 \% \\
1507\end{array}$ & / \\
\hline Primary ITP $(n=1)$ & $0 \%$ & $\begin{array}{c}100 \% \\
1200\end{array}$ & / \\
\hline Amyloidosis $(n=1)$ & $0 \%$ & $\begin{array}{c}100 \% \\
1200\end{array}$ & / \\
\hline $\begin{array}{l}\text { Hashimoto Thyroiditis } \\
(n=4)\end{array}$ & $\begin{array}{l}25 \% \\
2734\end{array}$ & $\begin{array}{c}75 \% \\
1200(1200- \\
1200)\end{array}$ & / \\
\hline Celiac Disease $(n=2)$ & $0 \%$ & $\begin{array}{c}100 \% \\
1268(1335- \\
1200)\end{array}$ & / \\
\hline Multiple sclerosis $(n=1)$ & $0 \%$ & $\begin{array}{c}100 \% \\
1817\end{array}$ & / \\
\hline
\end{tabular}


medRxiv preprint doi: https://doi.org/10.1101/2021.09.25.21263771; this version posted September 27, 2021. The copyright holder for this preprint (which was not certified by peer review) is the author/funder, who has granted medRxiv a license to display the preprint in perpetuity.

It is made available under a CC-BY-NC-ND 4.0 International license .

\begin{tabular}{|c|c|c|c|c|}
\hline & $\begin{array}{l}\text { Uncertain Autoimmune } \\
\text { Disease }(n=2)\end{array}$ & $0 \%$ & $\begin{array}{c}100 \% \\
1878(1716- \\
2039)\end{array}$ & I \\
\hline $\begin{array}{l}\text { Bacterial } \\
(n=2)\end{array}$ & Infection & $\begin{array}{c}100 \% \\
6450(3145-9755)\end{array}$ & $0 \%$ & I \\
\hline
\end{tabular}

Table S2: Patient characteristics in the cohort of SLE-mimicking conditions. Mann Whitney-U test or unpaired t-test were performed. 


\section{Figures:}

Figure 1: SIGLEC1 expression levels, analysed with flow cytometry on freshly isolated monocytes, are presented in patients with newly diagnosed SLE $(n=76)$ and SLE-mimicking conditions (No SLE, $\mathrm{n}=156$ ). For statistical analysis, the MannWhitney-U test was used. Median values and interquartile range are shown.

Figure 2: ROC curves analysis of ANA, SIGLEC1, anti-dsDNA antibodies, as well as C4 and C3 levels in a cohort of 76 newly diagnosed SLE patients and 156 SLEmimicking conditions.

Figure S1: SIGLEC1 levels in 26 SLE patients over time after initial diagnosis. $0=$ time of diagnosis, $3=$ after three months, $6=$ after six months. For statistical analysis, the Friedmann test $(p=0.0001)$ and the Dunn's multiple comparisons test was used: $0-3 \mathrm{M} p=0.004 ; 0-6: p=0.001 ; 3-6: p>0.999$. The read dotted line resembles change in median values over time.

Figure S2: SLEDAI Follow-Up 0 months, 3 months, and six months in 26 SLE patients. Statistical analysis using non-parametric Friedman test $p=0.0001$ and Dunn's multiple comparisons test: $0-3$ months: $p=0.0457,0-6$ months: $p=0.0005,3-6$ months: $p=0.7155$. The read dotted line resembles change in median values over time. 


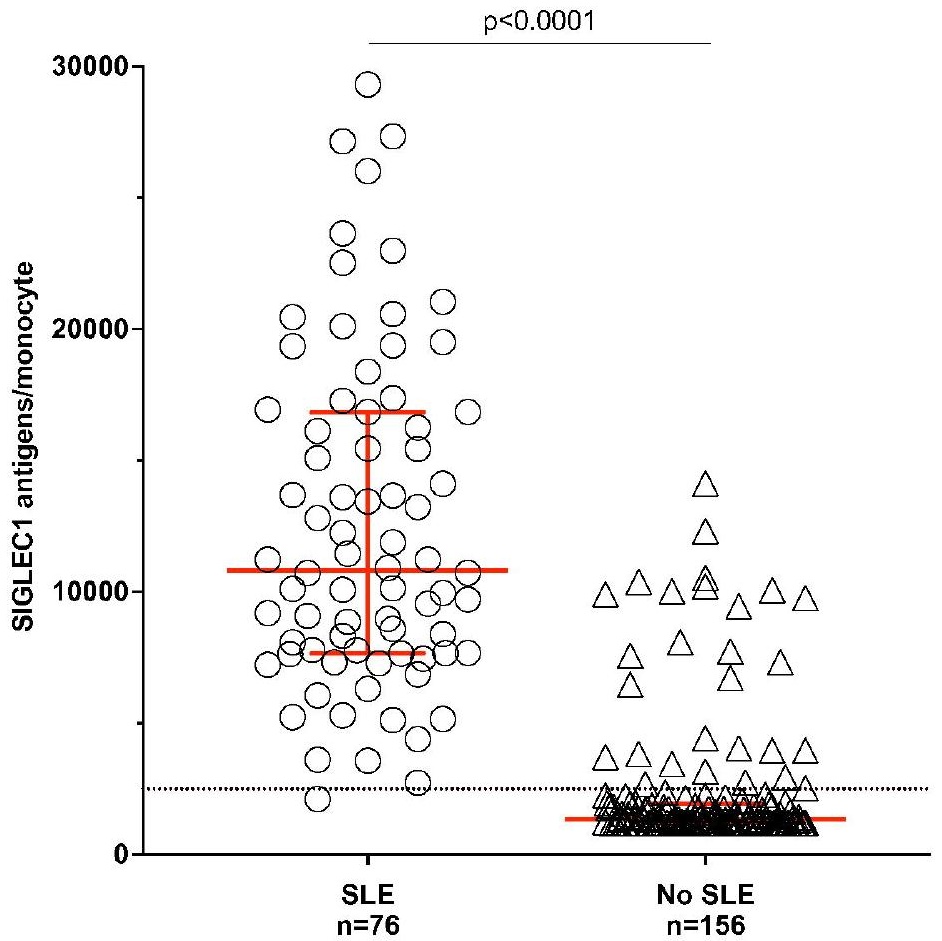




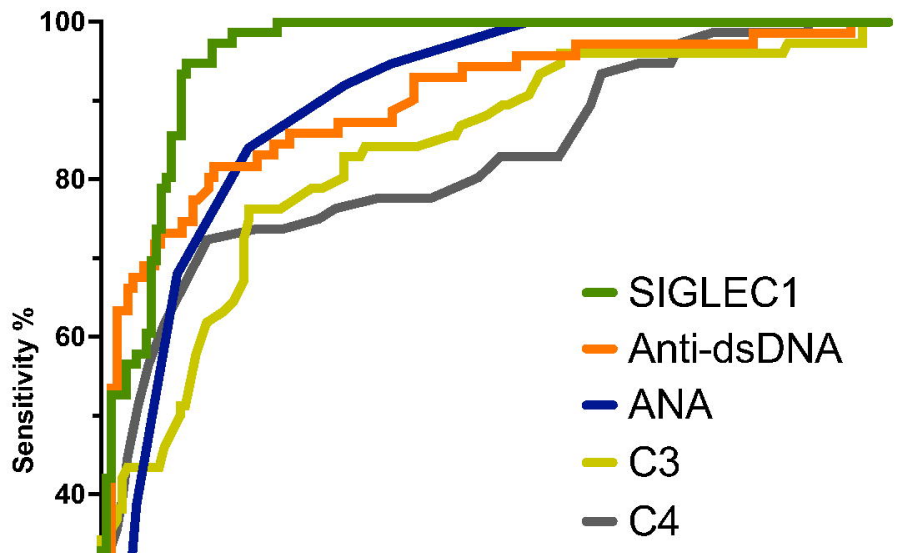




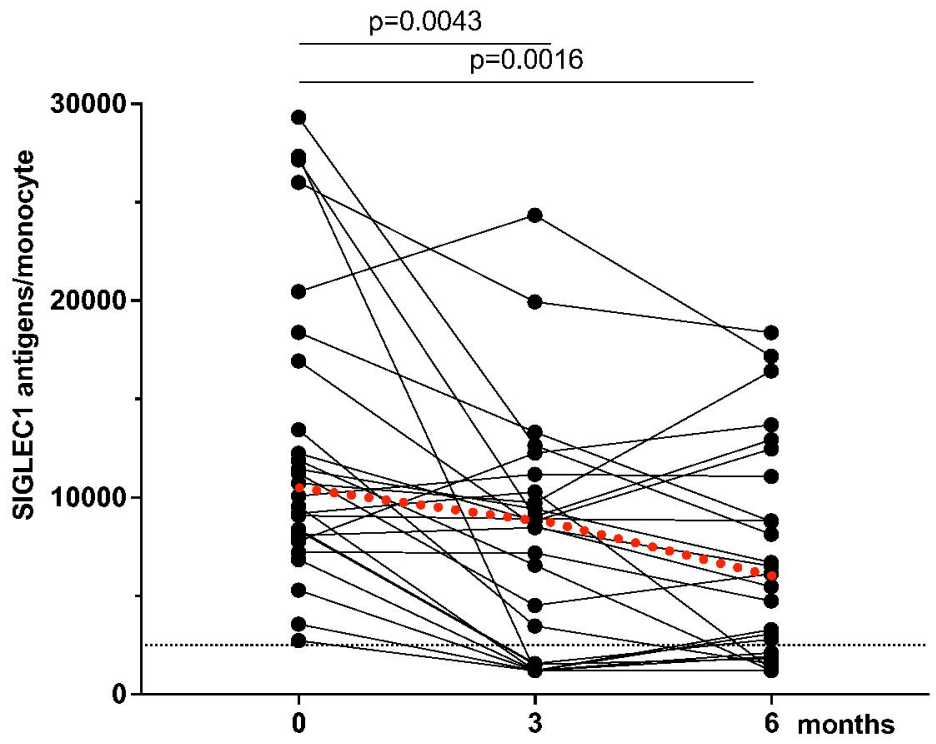


